\title{
Involvement of AMP-activated protein kinase in TGF- $\beta$-stimulated VEGF synthesis in osteoblasts
}

\author{
JUN MIZUTANI $^{1}$, HARUHIKO TOKUDA ${ }^{2,3}$, RIE MATSUSHIMA-NISHIWAKI ${ }^{2}$, KENJI KATO $^{1,2}$, \\ AKIRA KONDO $^{1,2}$, HIDEO NATSUME ${ }^{1,2}$, OSAMU KOZAWA ${ }^{2}$ and TAKANOBU OTSUKA ${ }^{1}$
}

\author{
${ }^{1}$ Department of Orthopedic Surgery, Nagoya City University Graduate School of Medical Sciences, Mizuho-Cho, \\ Mizuho-Ku, Nagoya 467-8601; ${ }^{2}$ Department of Pharmacology, Gifu University Graduate School of Medicine, Gifu 501-1194; \\ ${ }^{3}$ Department of Clinical Laboratory, National Center for Geriatrics and Gerontology, Morioka-Cho, Obu 474-8511, Japan
}

Received November 1, 2011; Accepted December 12, 2011

DOI: $10.3892 / \mathrm{ijmm} .2012 .893$

\begin{abstract}
It is generally recognized that AMP-activated protein kinase (AMPK) acts as a key regulator of energy homeostasis. We have previously shown that transforming growth factor- $\beta$ (TGF- $\beta$ ) stimulates synthesis of vascular endothelial growth factor (VEGF) via p44/p42 mitogen-activated protein (MAP) kinase, stress-activated protein kinase/c-Jun N-terminal kinase (SAPK/JNK) and p38 MAP kinase in osteoblast-like MC3T3-E1 cells. In the present study, we investigated whether AMPK is involved in the TGF- $\beta$-stimulated VEGF synthesis in osteoblast-like MC3T3-E1 cells. TGF- $\beta$ time-dependently induced the phosphorylation of the AMPK $\alpha$-subunit (Thr172) and the AMPK $\beta$-subunit (Ser108). Compound C, an AMPK inhibitor, significantly reduced the TGF- $\beta$-stimulated VEGF release. The inhibitory effect of compound $\mathrm{C}$ was also observed in normal human osteoblasts (NHOst). Although compound $\mathrm{C}$ failed to affect the TGF- $\beta$-induced phosphorylation of SAPK/ JNK, p38 MAP kinase or Smad2, it markedly suppressed the TGF- $\beta$-induced phosphorylation of both MEK1/2 and p44/p42 MAP kinase. In addition, compound C significantly suppressed the VEGF mRNA expression induced by TGF- $\beta$. Taken together, our results strongly suggest that AMPK is involved in TGF- $\beta$-stimulated VEGF synthesis, and that it functions at a point upstream of MEK1/2.
\end{abstract}

\section{Introduction}

Vascular endothelial growth factor (VEGF) is a potent mitogen displaying high specificity for vascular endothelial cells (1). VEGF, which is produced and secreted from a variety of cell types, increases capillary permeability and stimulates

Correspondence to: Dr Osamu Kozawa, Department of Pharmacology, Gifu University Graduate School of Medicine, 1-1 Yanagido, Gifu 501-1194, Japan

E-mail: okozawa@gifu-u.ac.jp

Key words: adenosine 5'-monophosphate-activated protein kinase, transforming growth factor- $\beta$, mitogen-activated protein kinase, vascular endothelial growth factor, osteoblast proliferation of endothelial cells (1). It is well known that the metabolism of bone tissue in the mammalian skeleton is a highly coordinated process of bone formation and bone resorption, regulated by osteoblasts and osteoclasts, respectively (2). The microvasculature is provided by capillary endothelial cells during bone remodeling. It is currently recognized that the activities of osteoblasts, osteoclasts, and capillary endothelial cells are closely coordinated, and properly regulate bone metabolism (3). These functional cells are considered to influence one another via humoral factors as well as by direct cell-to-cell contact. As for the regulation by VEGF of bone metabolism, it has been reported that an inactivation of VEGF causes complete suppression of blood vessel invasion concomitant with impaired trabecular bone formation and expansion of hypertrophic chondrocyte zone in mouse tibial epiphyseal growth plates (4). Osteoblasts synthesize VEGF in response to various physiological agents including transforming growth factor- $\beta$ (TGF- $\beta$ ) (5). We have shown that the TGF- $\beta$-stimulated VEGF synthetic cascade is positively regulated via mitogenactivated protein (MAP) kinase superfamily such as p44/p42 MAP kinase, p38 MAP kinase and stress-activated protein kinase/c-Jun N-terminal kinase (SAPK/JNK) in osteoblastlike MC3T3-E1 cells $(6,7)$. More recently, we have reported that Rho kinase negatively regulates the TGF- $\beta$-stimulated VEGF synthesis in MC3T3-E1 cells (8). These findings lead us to speculate that various kinds of intracellular molecules could modulate TGF- $\beta$-stimulated VEGF synthesis in osteoblasts. However, the exact mechanism underlying VEGF synthesis in osteoblasts has not yet been clarified.

Adenosine 5'-monophosphate-activated protein kinase (AMPK) is generally known to regulate multiple metabolic pathways (9). AMPK, defined as a mammalian protein kinase that was allosterically activated by AMP and was able to phosphorylate and inactivate enzymes of lipid synthesis (10), has emerged over the last decade as a key sensing mechanism in the regulation of cellular energy homeostasis (11-13). AMPK is activated in mammalian cells by a variety of physiological and pathological stresses that increase the intracellular AMP: ATP ratio, either by increasing ATP consumption or by decreasing ATP production. Compound $\mathrm{C}$, a pyrrazolopyrimidine derivative which competitively inhibits AMPK, has been widely used as a specific and reversible AMPK inhibitor (14-16). 
Activated AMPK acts to restore cellular energy balance by ATP generating pathways such as fatty acid oxidation, while simultaneously inhibiting ATP utilizing pathways. In addition to these functions as a metabolic regulator, it has been demonstrated that activated AMPK regulates bone formation and bone mass in vitro (17). However, the precise function of AMPK in the regulation of bone metabolism has not been fully elucidated.

In the present study, we investigated whether AMPK is involved in the TGF- $\beta$-stimulated VEGF synthesis in osteoblasts. We here show that AMPK is involved in TGF- $\beta$ stimulated VEGF synthesis in osteoblasts, and that AMPK acts at a point upstream of MEK1/2.

\section{Materials and methods}

Materials. Normal human osteoblasts (NHOst) were purchased from Cambrex (Charles, IA). TGF- $\beta$ and mouse or human VEGF enzyme-linked immunosorbent assay (ELISA) kit were purchased from R\&D Systems, Inc. (Minneapolis, $\mathrm{MN}$ ). Compound C, a pyrrazolopyrimidine derivative which competitively inhibits AMPK (16), was purchased from Calbiochem, Inc. (San Diego, CA). Phospho-specific AMPK $\alpha$ (Thr172) and (Ser485) antibodies, AMPK $\alpha$ antibodies, phospho-specific AMPK $\beta$ (Ser108) and (Ser182) antibodies, AMPK $\beta$, phospho-specific Smad2, Smad2, phospho-specific p44/p42 MAP kinase, p44/p42 MAP kinase, phospho-specific MEK1/2 and MEK1/2 antibodies were purchased from Cell Signaling Technology, Inc. (Beverly, MA). Glyceraldehyde-3phosphate dehydrogenase (GAPDH) antibodies were obtained form Santa Cruz Biotechnology, Inc. (Santa Cruz, CA). The ECL western blotting detection system was purchased from GE Healthcare UK Ltd. (Buckinghamshire, UK). Other materials and chemicals were obtained from commercial sources.

Cell culture. Cloned osteoblast-like MC3T3-E1 cells derived from newborn mouse calvaria (18) were maintained as previously described (19). Briefly, the cells were cultured in $\alpha$-minimum essential medium ( $\alpha$-MEM) containing $10 \%$ fetal calf serum (FCS) at $37^{\circ} \mathrm{C}$ in a humidified atmosphere of $5 \%$ $\mathrm{CO}_{2} / 95 \%$ air. The cells were seeded into $35-\mathrm{mm}$ diameter dishes $\left(5 \times 10^{4} / \mathrm{dish}\right)$ or $90-\mathrm{mm}$ diameter dishes $\left(20 \times 10^{4} / \mathrm{dish}\right)$ in $\alpha$-MEM containing $10 \%$ FCS. After 5 days, the medium was exchanged to $\alpha$-MEM containing $0.3 \%$ FCS and incubated for $48 \mathrm{~h}$. The cells were then used for subsequent experiments.

NHOst cells were seeded into $35-\mathrm{mm}\left(5 \times 10^{4} / \mathrm{dish}\right)$ diameter dishes in $\alpha$-MEM containing 10\% FCS (20). After 6 days, the medium was changed to $\alpha$-MEM containing $0.3 \%$ FCS. The cells were used for experiments after $48 \mathrm{~h}$.

VEGF assay. The cultured cells were pretreated with various doses of compound $\mathrm{C}$ for $60 \mathrm{~min}$, and then stimulated by $5 \mathrm{ng}$ / $\mathrm{ml}$ TGF- $\beta$ or vehicle in $1 \mathrm{ml}$ of $\alpha$-MEM containing $0.3 \%$ FCS for $48 \mathrm{~h}$. The conditioned medium was collected at the end of the incubation, and the VEGF concentration was measured by cell species-responsible ELISA kits. The absorbance of enzyme-linked immunosorbent assay (ELISA) samples was measured at $450 \mathrm{~nm}$ with the EL 340 Bio Kinetic Reader (Bio-Tek Instruments, Inc., Winooski, VT) according to the manufacturer's protocol.
Real-time RT-PCR. The cultured cells were pretreated with $10 \mu \mathrm{M}$ compound $\mathrm{C}$ or vehicle for $60 \mathrm{~min}$, and then stimulated by $5 \mathrm{ng} / \mathrm{ml}$ TGF- $\beta$ in a-MEM containing $0.3 \%$ FCS for the indicated periods. Total-RNA was isolated and transcribed into complementary DNA using TRIzol reagent (Invitrogen Corp., Carlsbad, CA) and Omniscript reverse transcriptase kit (Qiagen, Inc., Valencia, CA), respectively. Real-time RT-PCR was performed using a Light Cycler system in capillaries and FastStart DNA Master SYBR-Green I provided with the kit (Roche Diagnostics, Basel, Switzerland). Sense and antisense primers were synthesized based on the report of Simpson et al (21) for mouse VEGF mRNA. Sense and antisense primers for mouse VEGF mRNA were purchased from Takara Bio., Inc. (Tokyo, Japan) (primer set ID: MA039013). The amplified products were determined by melting curve analysis and agarose electrophoresis. VEGF mRNA levels were normalized with those of GAPDH mRNA.

Western blot analysis. Western blot analysis was performed as previously described (22). In brief, the cultured cells were pretreated with various doses of compound $\mathrm{C}$ for $60 \mathrm{~min}$, and then stimulated by $5 \mathrm{ng} / \mathrm{ml} \mathrm{TGF}-\beta$ or vehicle in $\alpha$-MEM containing $0.3 \%$ FCS for the indicated periods. The cells were washed twice with phosphate-buffered saline and then lysed, homogenized and sonicated in a lysis buffer containing $62.5 \mathrm{mM}$ Tris/ $\mathrm{HCl}, \mathrm{pH}$ 6.8, 3\% sodium dodecyl sulfate (SDS), $50 \mathrm{mM}$ dithiothreitol and 10\% glycerol. SDS-polyacrylamide gel electrophoresis (PAGE) was performed according to Laemmli (23) in $10 \%$ polyacrylamide gels. The protein $(10 \mu \mathrm{g})$ was fractionated and transferred onto an Immuno-Blot PVDF membrane (Bio-Rad, Hercules, CA). Membranes were blocked with 5\% fat-free dry milk in Tris-buffered saline-Tween-20 (TBS-T; $20 \mathrm{mM}$ Tris/HCl, pH 7.6, $137 \mathrm{mM} \mathrm{NaCl}, 0.1 \%$ Tween-20) for $2 \mathrm{~h}$ before incubation with the primary antibodies. Peroxidaselabeled antibodies raised in goat against rabbit IgG were used as second antibodies. The primary and secondary antibodies were diluted at 1:1,000 with 5\% fat-free dry milk in TBS-T. Peroxidase activity on the membrane was visualized on X-ray film by means of the ECL western blotting detection system.

Statistical analysis. The data were analyzed by ANOVA followed by the Bonferroni method for multiple comparisons between pairs, and a $\mathrm{P}<0.05$ was considered statistically significant. All data are presented as the mean \pm SEM of triplicate independent determinations.

\section{Results}

Effects of TGF- $\beta$ on the phosphorylation of AMPK subunits in MC3T3-E1 cells. In order to investigate whether TGF- $\beta$ stimulates the activation of AMPK in osteoblast-like MC3T3-E1 cells, we first examined the effects of TGF- $\beta$ on the phosphorylation of the AMPK subunits. TGF- $\beta$ markedly induced the phosphorylation of AMPK $\alpha$-subunit (Thr172) in a timedependent manner (Fig. 1A). The phosphorylation of the AMPK $\alpha$-subunit (Thr172) by TGF- $\beta$ reached its maximum at $2 \mathrm{~min}$, and decreased thereafter. TGF- $\beta$ also time-dependently induced the phosphorylation of the AMPK $\beta$-subunit (Ser108) (Fig. 1B). The phosphorylation level of AMPK $\beta$-subunit (Ser108) reached a peak at $15 \mathrm{~min}$, and decreased thereafter. However, TGF- $\beta$ had 
A
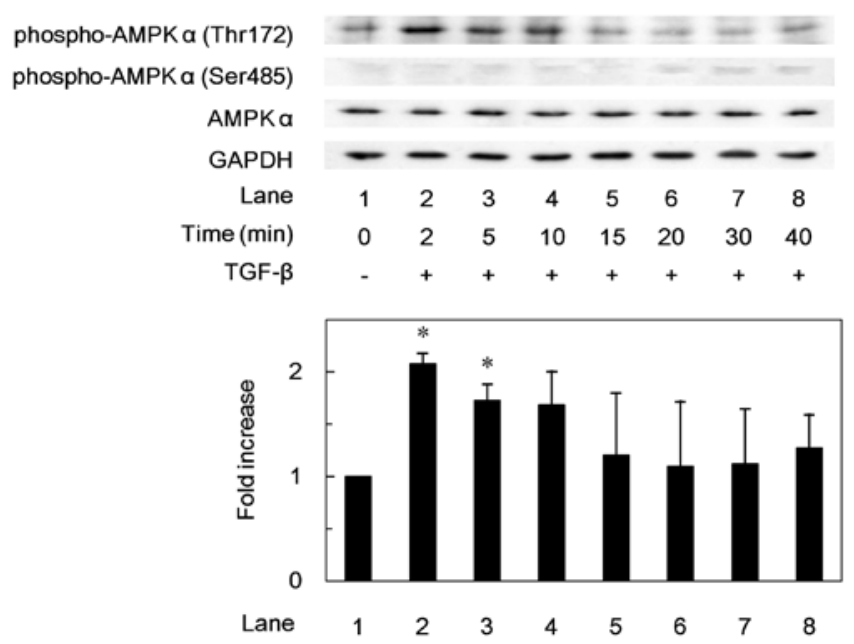

B
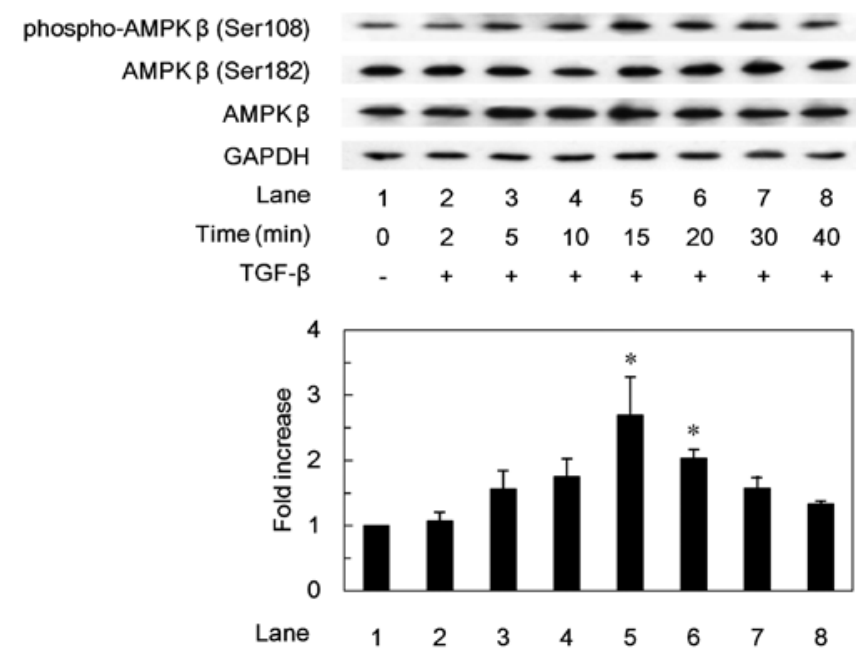

Figure 1. Effects of TGF- $\beta$ on the phosphorylation of (A) AMPK $\alpha$-subunits and (B) AMPK $\beta$-subunits in MC3T3-E1 cells. The cultured cells were stimulated by $5 \mathrm{ng} / \mathrm{ml}$ TGF- $\beta$ for the indicated periods. The extracts of cells were subjected to SDS-PAGE with subsequent western blot analysis with antibodies against phospho-specific AMPK $\alpha$ (Thr172), phospho-specific AMPK $\alpha$ (Ser485) antibodies, AMPK $\alpha$ antibodies, phospho-specific AMPK $\beta$ (Ser108), phospho-specific AMPK $\beta$ (Ser182), AMPK $\beta$ or GAPDH antibodies. The histgram shows quantitative representations of the levels of TGF- $\beta$ induced phosphorylation obtained from laser densitometric analysis of three independent experiments. Each value represents the mean \pm SEM of triplicate determinations. ${ }^{*} \mathrm{P}<0.05$, compared to the value of lane 1 .

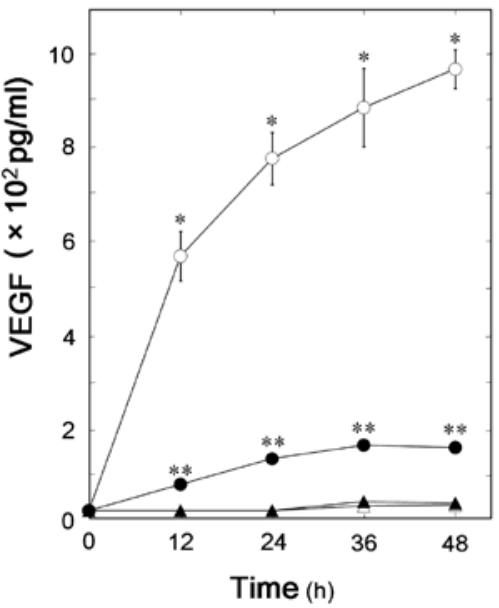

Figure 2. Effect of the AMPK inhibitor on the TGF- $\beta$-stimulated VEGF synthesis in MC3T3-E1 cells. The cultured cells were pretreated with $10 \mu \mathrm{M}$ AMPK inhibitor $(\bullet, \mathbf{\Delta})$ or vehicle $(O, \triangle)$ for $60 \mathrm{~min}$, and then stimulated by $5 \mathrm{ng} / \mathrm{ml}$ TGF- $\beta$ (circles) or vehicle (triangles) for the indicated periods. Each value represents the mean \pm SEM of three experiments performed by different cell preparations. ${ }^{*} \mathrm{P}<0.05$, compared to the value of control; ${ }^{* *} \mathrm{P}<0.05$, compared to the value of TGF- $\beta$ alone.

little effect on the phosphorylation of AMPK $\alpha$-subunit (Ser485) or AMPK $\beta$-subunit (Ser182) (Fig. 1).

Effect of compound $C$ on the TGF- $\beta$-stimulated VEGF synthesis in MC3T3-El cells. We have previously showed that TGF- $\beta$ significantly stimulates VEGF synthesis in osteoblastlike MC3T3-E1 cells (6). To investigate whether AMPK is involved in the TGF- $\beta$-stimulated VEGF synthesis in MC3T3-E1 cells, we next examined the effect of compound C, an inhibitor of AMPK, on VEGF synthesis stimulated by TGF- $\beta$. Compound $C$ significantly suppressed the TGF- $\beta$ induced VEGF synthesis (Fig. 2). The inhibitory effect of

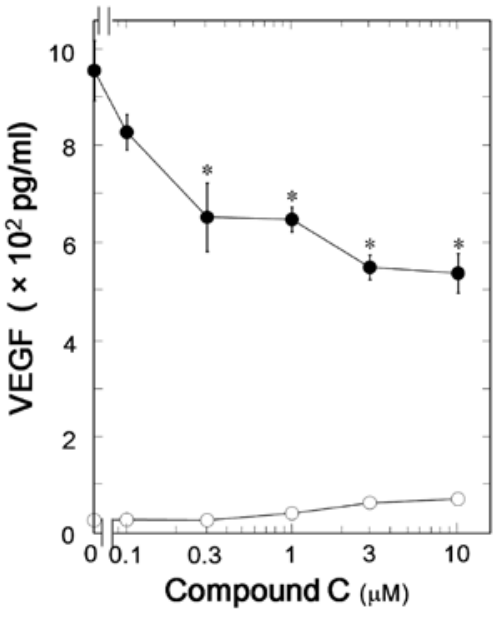

Figure 3. Effect of the AMPK inhibitor on the TGF- $\beta$-stimulated VEGF synthesis in MC3T3-E1 cells. The cultured cells were pretreated with various doses of AMPK inhibitor for $60 \mathrm{~min}$, and then stimulated by $5 \mathrm{ng} / \mathrm{ml}$ TGF- $\beta$ $(\bullet)$ or vehicle (O) for $48 \mathrm{~h}$. Each value represents the mean \pm SEM of three experiments performed by different cell preparations. ${ }^{\text {}} \mathrm{P}<0.05$, compared to the value of the control. compound $\mathrm{C}$ on the VEGF synthesis was dose-dependent in the range between 1 and $10 \mu \mathrm{M}$ (Fig. 3). The maximum effect of compound $\mathrm{C}$ was observed at $10 \mu \mathrm{M}$ and caused approximately $40 \%$ suppression in the TGF- $\beta$-effect.

Effect of compound $C$ on the TGF- $\beta$-stimulated VEGF synthesis in NHOst cells. We next examined the effects of compound $\mathrm{C}$ in NHOst, a different osteoblastic cell line. Compound C, as well as in MC3T3-E1 cells, significantly suppressed the TGF- $\beta$-induced VEGF synthesis in NHOst (Fig. 4). The inhibitory effect of compound $\mathrm{C}$ on the VEGF synthesis was dose-dependent in the range between 0.1 and $1 \mu \mathrm{M}$. The 


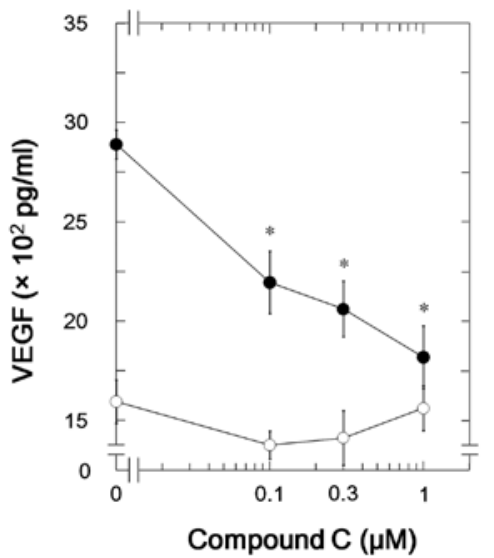

Figure 4. Effect of the AMPK inhibitor (compound C) on the TGF- $\beta$ stimulated VEGF synthesis in NHOst cells. The cultured cells were pretreated with various doses of AMPK inhibitor for $60 \mathrm{~min}$, and then stimulated by $5 \mathrm{ng} / \mathrm{ml} \mathrm{TGF}-\beta(\bullet)$ or vehicle (O) for $48 \mathrm{~h}$. Each value represents the mean \pm SEM of three experiments performed by different cell preparations. ${ }^{*} \mathrm{P}<0.05$, compared to the value of TGF- $\beta$ alone.

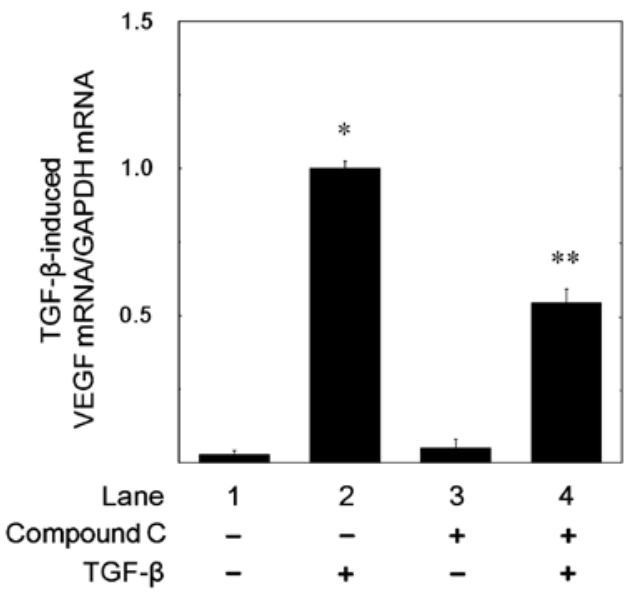

Figure 5.Effect of AMPK inhibitor on the TGF- $\beta$-stimulated expression levels of VEGF mRNA in MC3T3-E1 cells. The cultured cells were pretreated with $10 \mu \mathrm{M}$ AMPK inhibitor or vehicle for $60 \mathrm{~min}$, and then stimulated by $5 \mathrm{ng} / \mathrm{ml}$ TGF- $\beta$ for $12 \mathrm{~h}$. The respective total-RNA were then isolated and quantified by real-time RT-PCR. Results were standardized for the value of control. Each value represents the mean \pm SEM of three independent determinations performed by a single cell preparation. ${ }^{*} \mathrm{P}<0.05$, compared to the value of control; ${ }^{* *} \mathrm{P}<0.05$, compared to the value of TGF- $\beta$ alone.

maximum effect of compound $\mathrm{C}$ was observed at $1 \mu \mathrm{M}$ and caused approximately $80 \%$ suppression in the TGF- $\beta$-effect.

Effect of compound $C$ on the TGF- $\beta$-induced expression levels of VEGF mRNA in MC3T3-El cells. It has previously been reported that TGF- $\beta$ induces VEGF mRNA expression in MC3T3-E1 cells (5). In order to clarify whether AMPK affects TGF- $\beta$-stimulated VEGF release through the modulation of a transcriptional event or not, we furthermore examined the effect of compound $\mathrm{C}$ on the TGF- $\beta$-induced VEGF mRNA expression. We confirmed that VEGF mRNA expression levels induced by TGF- $\beta$ were increased in a time-dependent manner in accordance with a previous report (5). Compound C $(10 \mu \mathrm{M})$ significantly suppressed the TGF- $\beta$-induced VEGF mRNA expression levels (Fig. 5). Compound C of $10 \mu \mathrm{M}$
A

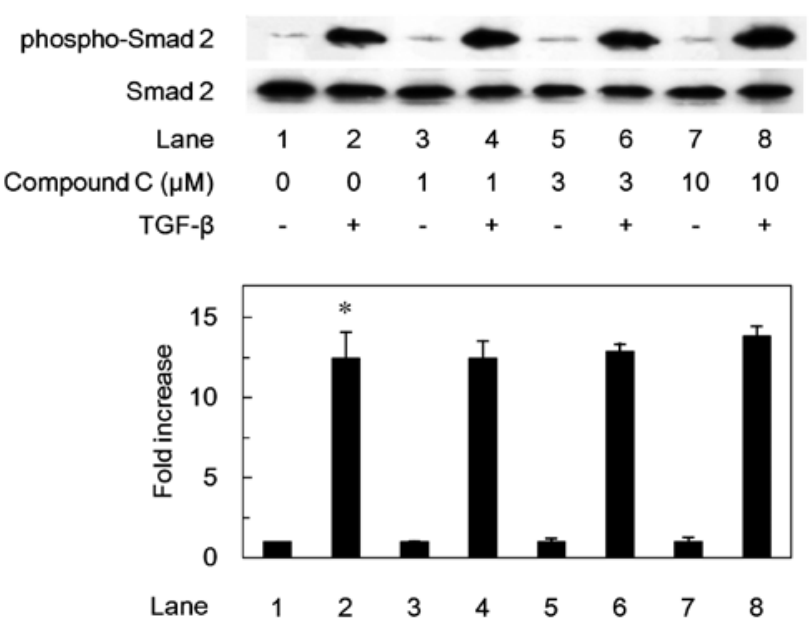

$\mathbf{B}$
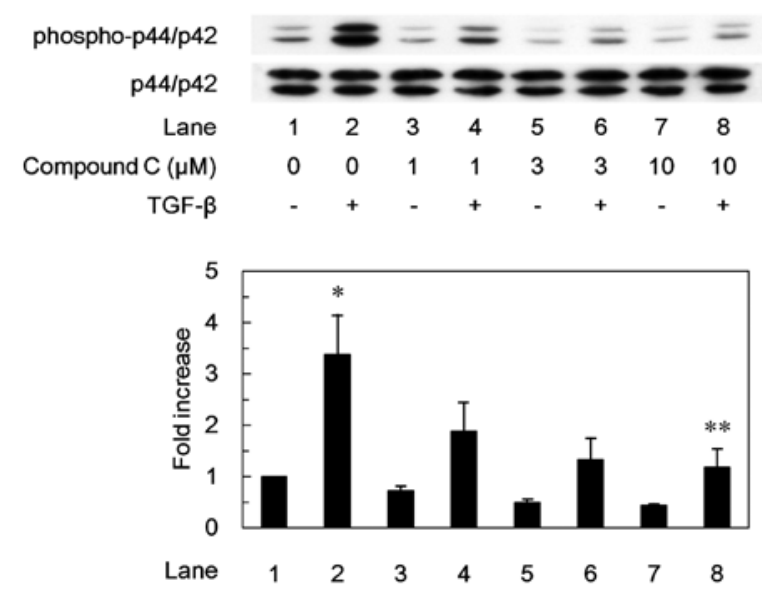

C
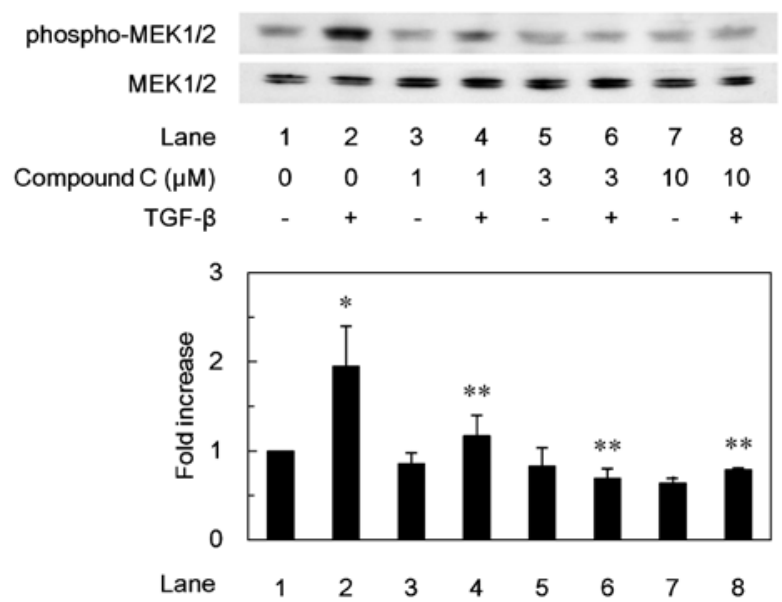

Figure 6. Effects of AMPK inhibitor on the TGF- $\beta$-induced phosphorylation of (A) Smad2, (B) p44/p42 MAP kinase and (C) MEK1/2 in MC3T3-E1 cells. The cultured cells were pretreated with various doses of AMPK inhibitor for $60 \mathrm{~min}$, and then stimulated with $5 \mathrm{ng} / \mathrm{ml}$ TGF- $\beta$ or vehicle for $120 \mathrm{~min}$. The cell extracts were then subjected to SDS-PAGE with subsequent western blot analysis with antibodies against phospho-specific Smad2, Smad2, phosphospecific p44/p42 MAP kinase, p44/p42 MAP kinase, phospho-specific MEK1/2 and MEK1/2. The histogram shows quantitative representations of the levels of TGF- $\beta$ induced phosphorylation obtained from laser densitometric analysis of three independent experiments. Each value represents the mean \pm SEM of triplicate determinations. " $\mathrm{P}<0.05$, compared to the value of lane $1 ;{ }^{* *} \mathrm{P}<0.05$, compared to the value of lane 2 . 
caused approximately 50\% inhibition in the TGF- $\beta$-effect. We confirmed that GAPDH mRNA was constitutively expressed and stable in MC3T3-E1 cells (data not shown).

Effects of compound $C$ on the phosphorylation of Smad2 or p44/p42 MAP kinase induced by TGF- $\beta$ in MC3T3-E1 cells. It is well known that receptor-activated Smads such as Smad2 are principal mediators of intracellular signaling from TGF- $\beta$ receptors to the nucleus (24). Thus, we next examined the effect of compound $\mathrm{C}$ on the TGF- $\beta$-induced phosphorylation of Smad2. However, compound C failed to affect the TGF- $\beta$ induced phosphorylation level of Smad2 in the range between 1 and $10 \mu \mathrm{M}$ (Fig. 6A).

It is currently recognized that other proteins mediate the intracellular signaling by TGF- $\beta$ in addition to Smads (25). We have previously demonstrated that $\mathrm{p} 44 / \mathrm{p} 42$ MAP kinase, p38 MAP kinase and SAPK/JNK are involved in the TGF- $\beta$ stimulated VEGF synthesis in osteoblast-like MC3T3-E1 cells $(6,7)$. In addition, we examined the effects of compound $C$ on the TGF- $\beta$-induced phosphorylation of p44/p42 MAP kinase, p38 MAP kinase or SAPK/JNK. Compound C markedly suppressed the TGF- $\beta$-induced phosphorylation level of $\mathrm{p} 44 /$ p42 MAP kinase in a dose-dependent manner between 1 and $10 \mu \mathrm{M}$ (Fig. 6B). Furthermore, compound $\mathrm{C}$ also suppressed TGF- $\beta$-stimulated phosphorylation of MEK1/2, an upstream kinase that activates p44/p42 MAPK (Fig. 6C). On the other hand, compound $\mathrm{C}$ had little effect on the phosphorylation of p38 MAP kinase or SAPK/JNK induced by TGF- $\beta$ (data not shown).

\section{Discussion}

AMPK exists as heterotrimeric complex comprising a catalytic $\alpha$-subunit and regulatory $\beta$ - and $\gamma$-subunits (9). Phosphorylation of the Thr172 residue in the $\alpha$-subunit is essential for AMPK activation (26). Once activated, AMPK causes an over 100-fold increase in kinase activity $(27,28)$. A carbohydrate binding module (CBM) is located within the central region of the $\beta$-subunit (9). In the CBM, multiple autophosphorylation sites including Ser108 have been identified (29). In the present study, we demonstrated that the maximum phosphorylation of the AMPK $\alpha$-subunit (Thr172) occurred at $5 \mathrm{~min}$, followed by a peak phosphorylation of the AMPK $\beta$-subunit (Ser108) at $15 \mathrm{~min}$. Although further examination is warranted to elucidate the precise mechanism of the relationship between AMPK activation and TGF- $\beta$ stimulation, our results strongly suggest that TGF- $\beta$ triggers phosphorylation of AMPK followed by a series of activation events of AMPK for TGF- $\beta$-stimulated VEGF synthesis in osteoblasts. In addition, we found that compound $C(15,16)$ also suppressed TGF- $\beta$-induced VEGF synthesis in NHOst cells. It is likely that AMPK is involved in TGF- $\beta$-induced VEGF synthesis also on human osteoblasts. To the best of our knowledge, this is the first report showing the involvement of AMPK in TGF- $\beta$-stimulated VEGF synthesis in osteoblasts.

It is well known that TGF- $\beta$ mainly employs receptor-activated Smad proteins such as Smad2 and Smad3 as intracellular mediators of signaling (30). However, compound C, an AMPK inhibitor, had no effect on the TGF- $\beta$-induced phosphorylation of Smad2 in osteoblast-like MC3T3-E1 cells. Therefore, it seems unlikely that AMPK acts at a point upstream of Smad2 in the VEGF synthesis in MC3T3-E1 cells. It is currently recognized that TGF- $\beta$ exerts its effects on a variety of biological functions via Smad-independent signaling in addition to Smad-dependent signaling (25). The MAP kinase superfamily, such as the p44/p42 MAP kinase, p38 MAP kinase and SAPK/JNK act as central elements used by mammalian cells to transduce the various extracellular messages $(24,31)$. As for TGF- $\beta$-stimulated VEGF synthesis in osteoblast-like MC3T3-E1 cells, we have reported the involvement of p44/p42 MAP kinase, p38 MAP kinase and SAPK/JNK (6,7). Thus, we investigated the effects of compound $C$ on the TGF- $\beta$-induced phosphorylation of these three MAP kinases. Compound C had little effect on the phosphorylation of SAPK/JNK or p38 MAP kinase induced by TGF- $\beta$. In contrast, TGF- $\beta$-induced phosphorylation of both $\mathrm{p} 44 / 42 \mathrm{MAP}$ kinase and MEK $1 / 2$ was markedly suppressed by compound C. These findings strongly suggest that AMPK acts at a point upstream of MEK1/2 in the TGF- $\beta$-stimulated VEGF synthesis in osteoblast-like MC3T3-E1 cells. TGF- $\beta$-activated kinase (TAK1), a member of the MAP kinase kinase kinase family, has been identified as an upstream kinase of MAP kinase including osteoblastlike MC3T3-E1 cells (32). It has been recently reported that expression of TAK1 in HeLa cells stimulates phosphorylation of the AMPK $\alpha$-subunit (Thr172) (33). Based on these findings, it is most likely that AMPK may act as a regulator at the point between TAK 1 and MEK $1 / 2$ in TGF- $\beta$-stimulated VEGF synthesis in osteoblast-like MC3T3-E1 cells. Recent reports have indicated that the possibility of AMPK-independent effects exerted by compound $\mathrm{C}(16,34,35)$. Thus, it is possible that an AMPK-independent mechanism is involved in compound C-induced suppression of TGF- $\beta$-stimulated VEGF synthesis in osteoblasts. However, there is no available inhibitor for AMPK which is more specific than compound C to the best of our knowledge. Further investigations would be required to clarify the details.

Recent studies have reported that both AMPK and VEGF play a significant role in bone metabolism $(1,17,36,37)$. Germline deletion of either AMPK $\beta 1$ or $\beta 2$ isoforms reportedly resulted in reduced trabecular bone density and mass without effects on osteoclast or osteoblast numbers, showing that AMPK is required to maintain normal bone density (38). Therefore, it is possible that TGF- $\beta$-induced VEGF synthesis via MEK1/2-p44/p42 MAP kinase regulated by AMPK plays an important role in the homeostasis of bone density under physiological conditions. Many hormones and neuromediators, including leptin, ghrelin, cannabinoids, and the sympathetic nervous system that regulate food intake and energy expenditure through AMPK activation also regulate bone mass (39-47). VEGF is critical for bone angiogenesis, and VEGF secreted from osteoblasts may play a pivotal role in the regulation of bone metabolism. It has been reported that TGF- $\beta$ induces differentiation or proliferation of osteoblasts, and inhibits the formation of osteoclast precursors (48). Therefore, it is highly speculated that TGF- $\beta$-stimulated VEGF synthesis via AMPK acts as a positive regulator of bone remodeling and AMPK is probably a key molecule in bone metabolism as seen in fat metabolism. We have recently reported that AMPK positively regulates FGF-2-stimulated VEGF synthesis via both p44/p42 MAP kinase and SAPK/JNK in osteoblast-like MC3T3-E1 
cells (49). It is likely that the regulatory mechanisms of VEGF synthesis by AMPK in osteoblasts are different in each stimulus, suggesting that the sophisticated regulation by AMPK is essential to promote the cellular event, VEGF synthesis. However, the exact role of AMPK in osteoblasts is not fully clarified. Further investigation is necessary to elucidate the role of AMPK in bone metabolism.

In conclusion, our results strongly suggest that AMPK functions at a point upstream of MEK $1 / 2$ and positively regulates TGF- $\beta$-stimulated VEGF synthesis via $444 / \mathrm{p} 42 \mathrm{MAP}$ kinase activation in osteoblasts.

\section{Acknowledgements}

We are very grateful to Yoko Kawamura for her skillful technical assistance. This investigation was supported in part by a Grant-in-Aid for Scientific Research (19591042) from the Ministry of Education, Science, Sports and Culture of Japan, the Foundation for Growth Science, and by Research Grants for Longevity Sciences (21A-4, 21A-22) from the Ministry of Health, Labour and Welfare of Japan.

\section{References}

1. Ferrara N: Vascular endothelial growth factor: basic science and clinical progress. Endocr Rev 25: 581-611, 2004.

2. Karsenty G and Wagner EF: Reaching a genetic and molecular understanding of skeletal development. Dev Cell 2: 389-406, 2002.

3. Erlebacher A, Filvaroff EH, Gitelman SE and Derynck R: Toward a molecular understanding of skeletal development. Cell 80: 371-378, 1995

4. Zelzer E and Olsen BR: Multiple roles of vascular endothelial growth factor (VEGF) in skeletal development, growth, and repair. Curr Top Dev Biol 65: 169-187, 2005.

5. Saadeh PB, Mehrara BJ, Steinbrech DS, Dudziak ME Greenwald JA, Luchs JS, Spector JA, Ueno H, Gittes GK and Longaker MT: Transforming growth factor- $\beta 1$ modulates the expression of vascular endothelial growth factor by osteoblasts Am J Physiol 277: C628-C637, 1999.

6. Tokuda H, Hatakeyama D, Akamatsu S, Tanabe K, Yoshida M, Shibata T and Kozawa O: Involvement of MAP kinases in TGF- $\beta$-stimulated vascular endothelial growth factor synthesis in osteoblasts. Arch Biochem Biophys 415: 117-125, 2003

7. Kanno Y, Ishisaki A, Yoshida M, Tokuda H, Numata $O$ and Kozawa O: SAPK/JNK plays a role in transforming growth factor- $\beta$-induced VEGF synthesis in osteoblasts. Horm Metab Res 37: $140-145,2005$

8. Kuno M, Takai S, Matsushima-Nishiwaki R, Minamitani C, Mizutani J, Otsuka T, Harada A, Adachi S, Kozawa O and Tokuda H: Rho-kinase inhibitors decrease TGF- $\beta$-stimulated VEGF synthesis through stress-activated protein kinase/c-Jun N-terminal kinase in osteoblasts. Biochem Pharmacol 77: 196-203, 2009.

9. Fogarty S and Hardie DG: Development of protein kinase activators: AMPK as a target in metabolic disorders and cancer. Biochim Biophys Acta 1804: 581-591, 2010.

10. Yeh LA, Lee KH and Kim KH: Regulation of rat liver acetyl-CoA carboxylase. Regulation of phosphorylation and inactivation of acetyl-CoA carboxylase by the adenylate energy charge. J Biol Chem 255: 2308-2314, 1980

11. Hardie DG, Hawley SA and Scott JW: AMP-activated protein kinase - development of the energy sensor concept. J Physiol 574 7-15, 2006

12. Lage R, Dieguez C, Vidal-Puig A, Lopez M. AMPK: a metabolic gauge regulating whole-body energy homeostasis. Trends Mol Med 14: 539-549, 2008.

13. Steinberg GR and Kemp BE: AMPK in health and disease. Physiol Rev 89: 1025-1078, 2009.

14. Zhou G, Myers R, Li Y, Chen Y, Shen X, Fenyk-Melody J, Wu M, Ventre J, Doebber T, Fujii N, et al: Role of AMP-activated protein kinase in mechanism of metformin activaiton. J Clin Invest 108: $1167-1174,2001$
15. Kim EK, Miller I, Aja S, Landree JE and Pinn M: C75, a fatty acid synthase inhibitor, reduces food intake via hypothalamic AMP-activated protein kinase. J Biol Chem 279: 19970-19976, 2004.

16. Nam M,Lee WH, Bae EJ and Kim SG: Compound C inhibits clonal expansion of preadipocytes by increasing p21 level irrespectively of AMPK inhibition. Arch Biochem Biophys 479: 74-81, 2008.

17. Shah M, Kola B, Bataveljic A, Arnett TR, Viollet B, Saxon L Korbonits M and Chenu C: AMP-activated protein kinase (AMPK) activation regulates in vitro bone formation and bone mass. Bone 47: 309-319, 2010.

18. Sudo H, Kodama HA, Amagai Y, Yamamoto S and Kasai S: In vitro differentiation and calcification in a new clonal osteogenic cell line derived from newborn mouse calvaria. J Cell Biol 96: 191-198, 1983.

19. Kozawa O, Tokuda H, Miwa M, Kotoyori J and Oiso Y: Cross-talk regulation between cyclic AMP production and phosphoinositide hydrolysis induced by prostaglandin E2 in osteoblast-like cells. Exp Cell Res 198: 130-134,1992.

20. Natsume H,Tokuda H, Adachi S, Takai S, Matsushima-NishiwakiR, Kato K, Minamitani C, Niida S, Mizutani J, Kozawa O, et al: Rho-kinase limits FGF-2-stimulated VEGF release in osteoblasts. Bone 46: 1068-1074, 2010.

21. Simpson DA, Feeney S, Boyle C and Stitt AW: Retinal VEGF mRNA measured by SYBR green I fluorescence: a versatile approach to quantitative PCR. Mol Vis 6: 178-183, 2000.

22. Kato K, Ito H, Hasegawa K, Inaguma Y, Kozawa O and Asano T: Modulation of the stress-induced synthesis of hsp27 and $\alpha \mathrm{B}$-crystallin by cyclic AMP in C6 rat glioma cells. J Neurochem 66: 946-950, 1996.

23. Laemmli UK: Cleavage of structural proteins during the assembly of the head of bacteriophage T4. Nature 227: 680-685, 1970.

24. Kyriakis JM and Avruch J: Mammalian mitogen-activated protein kinase signal transduction pathways activated by stress and inflammation. Physiol Rev 81: 807-889, 2001

25 . Moustakas A and Heldin CH: Non-Smad TGF- $\beta$ signals. J Cell Sci 118: 3573-3584, 2005.

26. Hawley SA, Davison M, Woods A, Davies SP, Beri RK, Carling D and Hardie DG: Characterization of the AMP-activated protein kinase kinase from rat liver and identification of threonine 172 as the major site at which it phosphorylates AMP-activated protein kinase. J Biol Chem 271: 27879-27887, 1996.

27. Stein SC, Woods A, Jones NA, Davison MD and Carling D: The regulation of AMP-activated protein kinase by phosphorylation. Biochem J 345: 437-443, 2000 .

28. Suter M, Riek U, Tuerk R, Schlattner U, Wallimann T and Neumann D: Dissecting the role of 5'-AMP for allosteric stimulation, activation, and deactivation of AMP-activated protein kinase. J Biol Chem 281: 32207-32216, 2006.

29. Mitchelhill KI, Michell BJ, House CM, Stapleton D, Dyck J, Gamble J, Ullrich C, Witters LA and Kemp BE: Posttranslational modifications of the 5'-AMP-activated protein kinase $\beta 1$ subunit. J Biol Chem 272: 24475-24479, 1997.

30. Miyazawa K, Shinozaki M, Hara T, Furuya T and Miyazono K: Two major Smad pathways in TGF- $\beta$ superfamily signalling. Genes Cells 7: 1191-1104, 2002.

31. Widmann C, Gibson S, Jarpe MB and Johnson GL: Mitogenactivated protein kinase: conservation of a three-kinase module from yeast to human. Physiol Rev 79: 143-180, 1999.

32. Yamaguchi K, Shirakabe K, Shibuya H, Irie K, Oishi I, Ueno N, Taniguchi T, Nishida E and Matsumoto K: Identification of a member of the MAPKKK family as a potential mediator of TGF- $\beta$ signal transduction. Science 270: 2008-2011, 1995.

33. Momcilovic M,Hong SPand Carlson M: Mammalian TAK1 activates Snf1 protein kinase in yeast and phosphorylates AMP-activated protein kinase in vitro. J Biol Chem 281: 25336-25343, 2006.

34. Emerling BM, Viollet B, Tormos KV and Chandel NS: Compound $\mathrm{C}$ inhibits hypoxic activation of HIF-1 independent of AMPK. FEBS Lett 581: 5727-5731, 2007.

35. Gao Y, Zhou Y, Xu A and Wu D: Effects of an AMP-activated protein kinase inhibitor, compound $\mathrm{C}$, on adipogenic differentiation of 3T3-L1 cells. Biol Pharm Bull 31: 1716-1722, 2008.

36. Wang DS, Yamazaki K, Nohtomi K, Shizume K, Ohsumi K, Shibuya M, Demura H and Sato K: Increase of vascular endothelial growth factor mRNA expression by 1,25-dihydroxyvitamin D3 in human osteoblast-like cells. J Bone Miner Res 11: 472-479, 1996

37. Gerber HP, Vu TH, Ryan AM, Kowalski J, Werb Z and Ferrara N: VEGF couples hypertrophic cartilage remodeling, ossification and angiogenesis during endochondral bone formation. Nat Med 5: 623-628, 1999. 
38. Quinn JMW, Tam S, Sims NA, Saleh H, McGregor NE, Poulton IJ, Scott JW, Gillespie MT, Kemp BE and van Denderen BJW: Germline deletion of AMP-activated protein kinase $\beta$ subunits reduces bone mass without altering osteoclast differentiation or function. FASEB J 24: 275-285, 2010.

39. Ducy P, Amling M, Takeda S, Priemel M, Schilling AF, Beil FT, Shen J, Vinson C, Rueger JM and Karsenty G: Leptin inhibits bone formation through a hypothalamic relay: a central control of bone mass. Cell 100: 197-207, 2000.

40. Baldock PA, Sainsbury A, Couzens M, Enriquez RF, Thomas GP, Gardiner EM and Herzog H: Hypothalamic Y2 receptors regulate bone formation. J Clin Invest 109: 915-921, 2002.

41. Cornish J, Callon KE, Bava U, Lin C, Naot D, Hill BL, Grey AB, Broom N, Myers DE, Nicholson GC, et al: Leptin directly regulates bone cell function in vitro and reduces bone fragility in vivo. J Endocrinol 175: 405-415, 2002.

42. Elefteriou F, Ahn JD, Takeda S, Starbuck M, Yang X, Liu X, Kondo H, Richards WG, Bannon TW, Noda M, et al: Leptin regulation of bone resorption by the sympathetic nervous system and CART. Nature 434: 514-520, 2005.

43. Idris AI, van't Hof RJ, Greig IR, Ridge SA, Baker D, Ross RA and Ralston SH: Regulation of bone mass, bone loss and osteoclast activity by cannabinoid receptors. Nat Med 11: 774-779, 2005 .
44. Maccarinelli G, Sibilia V, Torsello A, Raimondo F, Pitto M, Giustina A, Netti C and Cocchi D: Ghrelin regulates proliferation and differentiation of osteoblastic cells. J Endocrinol 184: 249-256, 2005.

45. Ahn JD, Dubern B, Lubrano-Berthelier C, Clement K and Karsenty G: Cart overexpression is the only identifiable cause of high bone mass in melanocortin 4 receptor deficiency. Endocrinology 147: 3196-3202, 2006.

46. Sato S, Hanada R, Kimura A, Abe T, Matsumoto T, Iwasaki M, Inose H, Ida T, Mieda M, Takeuchi Y, et al: Central control of bone remodeling by neuromedin U. Nat Med 13: 1234-1240, 2007.

47. Hamrick MW and Ferrari SL: Leptin and the sympathetic connection of fat to bone. Osteoporos Int 19: 905-912, 2008.

48. Bonewald LF and Mundy GR: Role of transforming growth factor- $\beta$ in bone remodeling. Clin Orthop Relat Res 261-276, 1990.

49. Kato K, Tokuda H, Adachi S, Matsushima-Nishiwaki R, Natsume H, Yamakawa K, Gu Y, Otsuka T and Kozawa O: AMP-activated protein kinase positively regulates FGF-2-stimulated VEGF synthesis in osteoblasts. Biochem Biophys Res Commun 400: 123-127, 2010. 